\title{
A Model for the Prediction of Tobacco Temperature and Oxygen Profiles in Warehouse Aging Process*
}

\author{
by \\ Yizhou Zheng, John Chipley, Alan Dow, and Carl Midgett \\ Department of R\&D, US Smokeless Tobacco Inc., 800 Harrison Street, Nashville, TN 37203, USA
}

\section{SUMMARY}

A mathematical model on the temperature and oxygen profiles for the tobacco warehouse aging process was formulated and solved by numeric analysis. The model parameters were obtained using the non-linear regression method by fitting several years measured temperatures to the model. The $R$ square value between measured and calculated tobacco temperatures in warehouse aging process are all over 0.95 . The proposed model can be used to predict the tobacco hogshead temperature profile at different time and positions with ambient temperature, tobacco moisture contents and $\mathrm{pH}$. At the same time, the model also predicts the oxygen profile in the hogshead. The effects of the ambient temperature, $\mathrm{pH}$, void fraction, the reaction active energy, oxygen diffusivity, and the oxygen consumption rate constant on the temperature profile were studied. [Beitr. Tabakforsch. Int. 22 (2007) 358-364]

\section{ZUSAMMENFASSUNG}

Ein mathematisches Modell für die Temperatur- und Sauerstoffprofile während des Alterungsprozesses des Tabaks in Tabakspeichern wurde entwickelt und durch numerische Analyse gelöst. Die Modellparameter wurden mittels einer nichtlinearen Regressionsmethode ermittelt, indem die über mehrere Jahre gemessenen Temperaturen in das Modell eingesetzt wurden. Die $R^{2}$-Werte zwischen den gemessenen und berechneten Temperaturen in den Tabakspeichern während des Aging-Prozesses lagen alle über 0,95. Das vorgeschlagene Modell kann dazu herangezogen werden, die Temperaturprofile in den Tabakspeichern zu verschiedenen Zeiten und an unterschiedlichen Positionen anhand der Umgebungstemperatur, des Feuchtigkeitsgehalts des Tabaks und des $\mathrm{pH}-$ Wertes vorherzusagen.
Gleichzeitig lässt sich anhand des Modells das Sauerstoffprofil in den Schuppen vorhersagen. Die Auswirkungen der Umgebungstemperatur, des pH-Wertes, des Hohlraumes, der aktiven Reaktionsenergie, der Sauerstoffdiffusion und die Konstante des Sauerstoffverbrauchs auf die Temperaturprofile wurden untersucht. [Beitr. Tabakforsch. Int. 22 (2007) 358-364]

\section{RESUME}

Un modèle mathématique sur l'évolution de la température et de l'oxygène pour décrire le processus de maturation pendant le stockage a été développé par analyse numérique. Les paramètres du modèle ont été conçus par régression non linéaire, en enrichissant le modèle avec les températures mesurées au cours de plusieurs années. La valeur $R^{2}$ entre les températures du tabac mesurées et calculées au cours de la maturation pendant le stockage dans les entrepôts de tabac est supérieur à 0.95 . Le modèle proposé permet de prédire l'évolution de la température dans les cartons de tabac entreposés à différents moments et positions par la température ambiante, le taux d'humidité du tabac et le $\mathrm{pH}$. De plus, le modèle prédit le profil d'oxygène dans les entrepôts. Les effets de la température ambiante, le $\mathrm{pH}$, la fraction de vide, l'énergie de réaction active, la diffusivité de l'oxygène, et le taux de consommation d'oxygène sur le profil de température ont été examinés. [Beitr. Tabakforsch. Int. 22 (2007) 358-364]

\section{INTRODUCTION}

Tobacco warehouse aging is a process where tobacco leaves are packed in hogsheads and stored at ambient temperature for a few years. During this period of time, biological 
reactions occur in the packed tobacco leaves. Chemical compositions can then be changed which also results in the $\mathrm{pH}$ changing in the tobacco leaves. In turn, the $\mathrm{pH}$ value and the moisture level of the tobacco leaves as well as the ambient room temperature all affect the biological activity. These factors are dependent upon one another in the process.

As an important process, tobacco aging in warehouse greatly influences the tobacco flavor and has been studied in the tobacco industry. This is a complicated process and many chemical and physical changes are involved. Many studies have been published focusing on the relationships among chemical components, temperature, moisture, and $\mathrm{pH}$. Measured temperature profiles represent a lot of physical and chemical information because of its accuracy and continuity. Unfortunately, quantitative studies on the relationship between temperature and other factors are not available from the literature.

Temperature studies in a solid state fermentation process which is similar to tobacco warehouse aging have been published. Applied with macroscopic energy balance, a pseudo-homogeneous one-dimensional model has been proposed to simulate the temperature profile in a solid state fermentation system (1-3). For a solid state bioreactor of sorghum mash, LAI et al. (4) established a thermal conduction model and reported a one-dimensional pseudo-steady heat conduction model. VANDERGHEYNST (5) studied energy transport in a high-solid aerobic degradation process. However, the models mentioned above, due to simplified assumptions, can not be employed to calculate dynamic temperature profiles well. Although SEKI et al. (6, 7 ) estimated the heat generated from the composting process by investigating the heat transfer, a number of polynomial parameters in their model were difficult to determine by experiments or by numerical analyses. For a non-isothermal static compost process, HsIEH et al. (8) proposed a theoretical model to calculate dynamic temperatures and mass distributions of the reacting components. But there is no comparison between the theoretical and experimental results and many model parameters were generated without experimental or published data. Using regression analysis, ROBINZON et al. (9) calculated three bulk parameters of a composting process in windrows by introducing a specific rate function which eventually limited the application of this model. The model did not predict the temperatures well in the initial ten day period even though they used the improved rate function generated from experiments.

Unlike other solid state fermentation processes, tobacco warehouse aging is not only complicated but is also a very slow process lasting a number of years. During this period of time, the ambient temperature greatly changes due to the different seasons. In the summer, biological reactions could actively consume the dissolved oxygen and change other compounds also, and then the biological activity could gradually decrease or stop when approaching the winter. The oxygen content in tobacco could be replaced by diffusion from the room at low temperatures in the winter. These dynamic phenomena could occur alternately over years governed by the ambient temperature, time, biological activity, $\mathrm{pH}$ and moisture.

This work was undertaken to establish a mathematical model for describing dynamic temperature and dissolved oxygen based on general equations of heat and mass balance.
Tobacco properties are estimated in terms of published results. All model parameters with given physical or chemical significance have been obtained using the non-linear regression method by fitting the measured temperatures to the model. Effects of model parameters such as the void fraction, reaction active energy, and the reaction rate on the temperature profile have been studied.

\section{EXPERIMENTAL}

In a large warehouse aging study, tobacco leaves from different varieties and different moisture contents (22-27\%) were packed in seventy-six hogsheads each with a height of 1.22 meter and a diameter of 1.22 meter. After a preliminary screening of the seventy-six hogsheads at prizing, eight hogsheads were selected for a controlled atmosphere study. Pairs of high and low moisture hogsheads were split into two groups and placed on their sides in two rooms so that initially two different ambient temperature conditions could be established for the aging study.

The room temperature was $26.7^{\circ} \mathrm{C}$ for one cure room, while it was $21.1^{\circ} \mathrm{C}$ for another cure room at the start of the study and during each of the summer intervals. The relative humidity was maintained at $55-60 \%$ in both rooms throughout the study. The temperature of the rooms was changed at intervals approximating seasonal changes.

Each hogshead was drilled and samples were taken for analysis at certain intervals. These analyses included $\mathrm{pH}$, moisture, organic acids, and some other chemical components. The temperature probes were inserted into the center of the hogsheads to continuously record temperature. The ambient temperatures in these rooms were also recorded at the same time intervals. Biological activity or reactions may include those from microorganisms and from the tobacco leaves although specific assays were not conducted.

\section{MATHEMATICAL MODEL}

\section{Oxygen in bulk phase and dissolved oxygen in solid phase}

Applied with the principles of heat and mass balance, the general equation (10) describing oxygen profiles in bulk phase of a hogshead system in cylindrical coordinates can be written as

$$
\frac{\partial C}{\partial t}=D \cdot\left[\frac{1}{r} \cdot \frac{\partial}{\partial r}\left(r \cdot \frac{\partial C}{\partial r}\right)\right]+\frac{1-\epsilon}{\epsilon} \cdot R_{\mathrm{i}}+K_{\mathrm{LA}} \cdot\left(C_{\mathrm{IS}}-C\right)
$$

where $R_{\mathrm{i}}$ denotes the reaction rate of the oxygen consumption, and $K_{\mathrm{LA}}$ is the oxygen mass transfer coefficient from the internal wall's oxygen concentration $\left(C_{\mathrm{IS}}\right)$ into anywhere inside the hogshead. It is assumed that the oxygen mass transfer can be a linear driving force process. The initial condition:

$$
C(t=0, r=r)=C_{0}
$$

At the center of the hogshead:

$$
\frac{\partial C(t=t, r=0)}{\partial r}=0
$$


It is assumed that the oxygen in ambient air can be transferred to the internal wall of the hogshead and this mass transfer can also be assumed to be a process with a linear driving force. Thus, the boundary condition at the internal wall of the hogshead can be:

$$
\frac{\partial C_{\mathrm{IS}}}{\partial t}=\frac{1-\epsilon}{\epsilon} \cdot R_{\mathrm{i}}+K_{\mathrm{c}} \cdot\left(C_{0} C_{\mathrm{IS}}\right)
$$

where $K_{\mathrm{c}}$ is the oxygen mass transfer coefficient from the external into the internal wall of the hogshead. The oxygen consumption rate can be assumed as a first order reaction as follows.

$$
R_{\mathrm{i}}=-k_{i} \cdot C_{\text {dissolved }}
$$

where $k_{i}$ is the rate constant and $\mathrm{C}_{\mathrm{dissolved}}$ is the dissolved oxygen concentration in solid phase. As is well known, the rate constant is a function of temperature and it can be expressed as:

$$
k_{i}=k_{0} \cdot \operatorname{Exp}\left(-\frac{E_{02}}{R \cdot T}\right)
$$

where $E_{\mathrm{O}_{2}}$ denotes the active energy of the reaction. It is assumed that oxygen in the bulk phase can be transferred to the solid phase only through Henry's law because of the dilute solution. The dissolved oxygen in the solid phase participates in the reactions of oxygen consumption. In the temperature range from $T=13-32{ }^{\circ} \mathrm{C}$, Henry's constant can be taken as a constant to be $4.4 \times 10^{4}$ (atm). Thus, the relationship between oxygen concentration in bulk phase and in solid phase could be as follows.

$$
C_{\text {dissolved }}=0.99 \cdot C
$$

\section{Temperature}

The general equation describing temperature profiles for a hogshead system in cylindrical coordinates can be written as

$$
\rho \cdot C_{\rho} \cdot \frac{\partial T}{\partial t}=k_{\rho} \cdot\left[\frac{1}{r} \cdot \frac{\partial}{\partial r}\left(r \cdot \frac{\partial T}{\partial r}\right)\right]+\frac{1-\epsilon}{\epsilon} \cdot \sum \Delta H_{\mathrm{j}} \cdot R_{\mathrm{j}}
$$

where $R_{\mathrm{j}}$ and $\Delta H_{\mathrm{j}}$ denote the rate and the corresponding enthalpy for the reaction $j$. Because of the complex reactions, the sum for the products of the reaction rate and the corresponding enthalpy can be lumped together and treated as a function related to oxygen concentrations, $\mathrm{pH}$, and temperature profiles. Then, equation (8) can be written as

$$
\begin{gathered}
\frac{\partial T}{\partial t}=\alpha \cdot\left[\frac{1}{r} \cdot \frac{\partial}{\partial r}\left(r \cdot \frac{\partial T}{\partial r}\right)\right]+\frac{1-\epsilon}{\epsilon} \cdot \frac{\sum \Delta H_{\mathrm{j}} \cdot R_{\mathrm{j}}}{\rho \cdot C_{\mathrm{p}}} \\
\sum \Delta H_{\mathrm{j}} \cdot R_{\mathrm{j}}=\beta \cdot \operatorname{Exp}\left(-\frac{E_{\mathrm{T}}}{R \cdot T}\right) \cdot\left(\frac{C}{H_{\mathrm{O}_{2}}+C}\right) \\
\cdot[1+a \cdot \mathrm{pH} \cdot(\mathrm{pH}-b)]
\end{gathered}
$$

where the symbol $\beta$ is defined as a product of the reaction enthalpies and their rates without effects of temperature, oxygen and $\mathrm{pH} . E_{\mathrm{T}}$ denotes the reaction active energy. $H_{\mathrm{O}_{2}}$ is the oxygen factor reflecting the effect of oxygen concentration on the temperature. Parameters a and b represent the effect of $\mathrm{pH}$ on the temperature.

The initial condition:

$$
T(t=0, r=r)=T_{0}
$$

At the center:

$$
\frac{\partial T(t=t, r=0)}{\partial r}=0
$$

Apparently the temperature at the internal wall of the hogshead is affected by both the external wall temperature which is the ambient temperature and the temperature in the hogshead close to the internal wall. The internal wall temperature thus can be estimated by the following equation.

$$
\begin{aligned}
& \frac{\partial T\left(t=t, r=r_{0}\right)}{\partial t}=\alpha_{\mathrm{w}} \cdot \frac{\partial T}{\partial x^{2}} \\
& T\left(t=t, r=r_{0}+\delta\right)=T_{\mathrm{R}}
\end{aligned}
$$

\section{Estimation of tobacco properties}

The heat capacity of tobacco is a function of its moisture contents. At room temperature, published data (11) can be correlated as a relationship between them as follows.

$$
C_{\mathrm{p}}=0.4606+0.1244 \cdot \tanh (37.0419 \cdot \mathrm{OV}-2.4430)
$$

The thermal diffusivity of tobacco is also determined by its moisture content in a certain temperature range. The correlation from published data (11) can be obtained to estimate the tobacco thermal diffusivity from the moisture content over the range of $10-100 \%$ water, on a dry weight basis at room temperature.

$$
\alpha=\frac{0.0114 \cdot \mathrm{OV}}{0.0640+\mathrm{OV}}
$$

\section{RESULTS AND DISCUSSION}

The proposed model including Eqns. [1] to [12] can be solved simultaneously by numerical analysis (12). The tobacco properties such as heat capacity and thermal diffusivity can be estimated from Eqns. [13] and [14]. The thermal diffusivity for the hogshead material is available from the Handbook of Chemical Engineering. The model parameters $a$ and $b$ reflecting the effect of $\mathrm{pH}$, the active reaction energies $E_{\mathrm{T}}$ and $E_{\mathrm{O}_{2}}, H_{0_{2}}$ reflecting the effect of oxygen on the temperature, $\beta$ being the product of the reaction enthalpy and the rate, and $\mathrm{k}_{0}$ being a rate constant of oxygen consumed at $0{ }^{\circ} \mathrm{C}$ could be obtained using nonlinear regression by fitting several years' measured temperatures to the model. Table 1 lists the model parameters.

Temperatures of a few years for eight hogsheads with different varieties of tobacco packed inside with different moisture contents were estimated using the proposed model. An example of tobacco temperature profiles has been shown in Figure 1 which indicates the comparison 
Table 1. Model parameters correlated from measured temperatures in hogsheads

\begin{tabular}{l|l}
\hline Parameters & Values \\
\hline a, dimensionless & 0.2454 \\
$b$, dimensionless & 5.8004 \\
$E_{\mathrm{T}}, \mathrm{cal} / \mathrm{mol}$ & 165.5905 \\
$\beta, \mathrm{kcal} / \mathrm{m}^{3}$ day & 14309.1445 \\
$H_{0_{2}}, \mathrm{mmol} / \mathrm{L}$ & 0.1405 \\
$\mathrm{k}_{0}, 1 /$ day & 64.7249 \\
$E_{0_{2}}, \mathrm{cal} / \mathrm{mol}$ & 165.5905 \\
$K_{\mathrm{LA}}, 1 /$ day & 0.1035 \\
$D, \mathrm{~m}^{2} /$ day & 0.0096 \\
$K_{\mathrm{c}}, 1 /$ day & 0.1035 \\
\hline
\end{tabular}

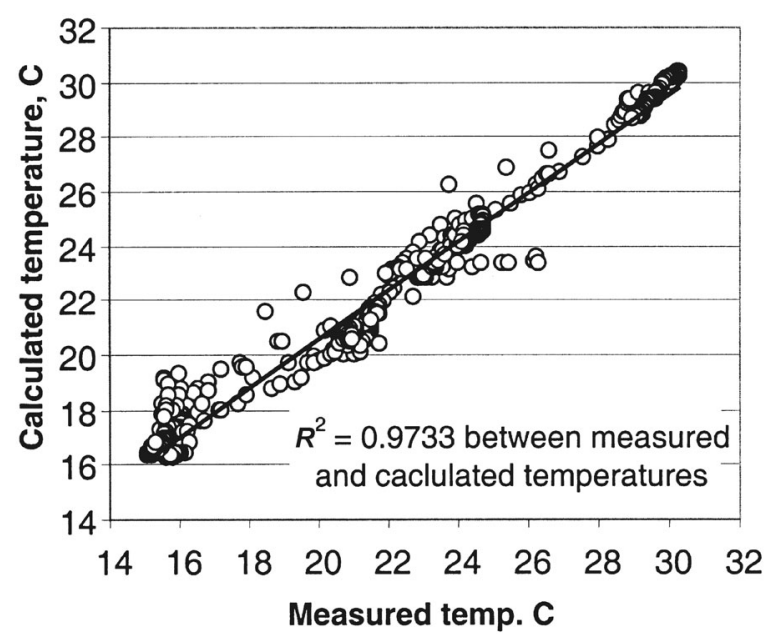

Figure 1. Comparison between the measured temperatures in hogshead center and calculated temperatures using the proposed model for one kind of tobacco placed in a controlled atmosphere room for a few years

between measured tobacco temperatures in the hogshead center and estimated temperatures using the model. The hogshead was placed in a controlled atmosphere with varied ambient temperatures and the relative humidity maintained at $55-60 \%$. The $R$ square value between measured and calculated temperatures has been estimated to reach up to 0.97 . It should be noted that the calculated temperature profiles for all eight hogsheads are in an excellent agreement with the measured temperature profiles and the $R$ square values between them are all over 0.95 .

\section{The effect of room temperature}

The temperature and oxygen profiles in the hogshead are dependent upon many factors such as biological reaction rates, the mass transfer process, packing conditions, and varied ambient temperature. In order to observe their profiles clearly, simulated temperatures and oxygen concentrations at different positions in a hogshead placed in a cure room with a constant temperature are shown in Figures 2 to 5. Figures 2 to 3 indicate the situation with a constant room temperature of $15.6{ }^{\circ} \mathrm{C}$, while that at a constant room temperature of $26.7^{\circ} \mathrm{C}$ is represented by Figures 4 to 5 . When the local concentration of dissolved oxygen is dropped to about $2 \mathrm{mg} / \mathrm{L}$, an anaerobic zone will appear

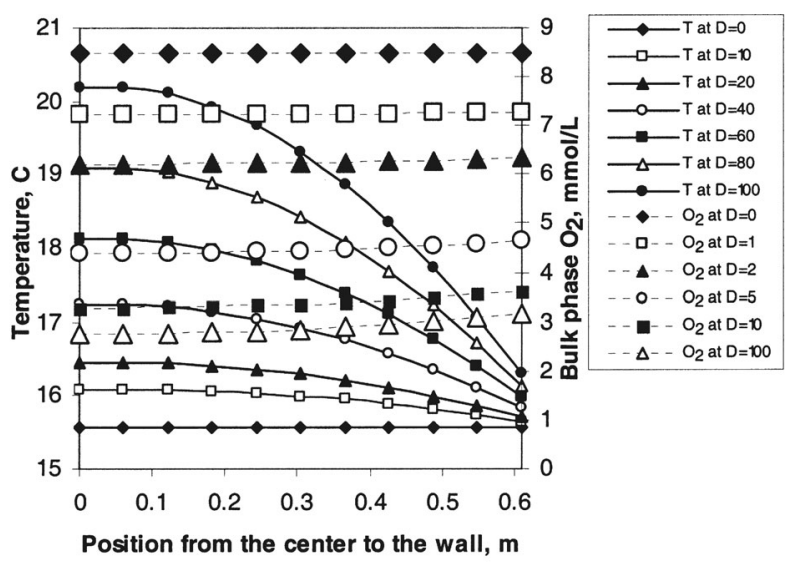

Figure 2. The temperature and oxygen profiles at different positions in the hogshead placed in a cure room with a constant temperature of $15.6^{\circ} \mathrm{C}$

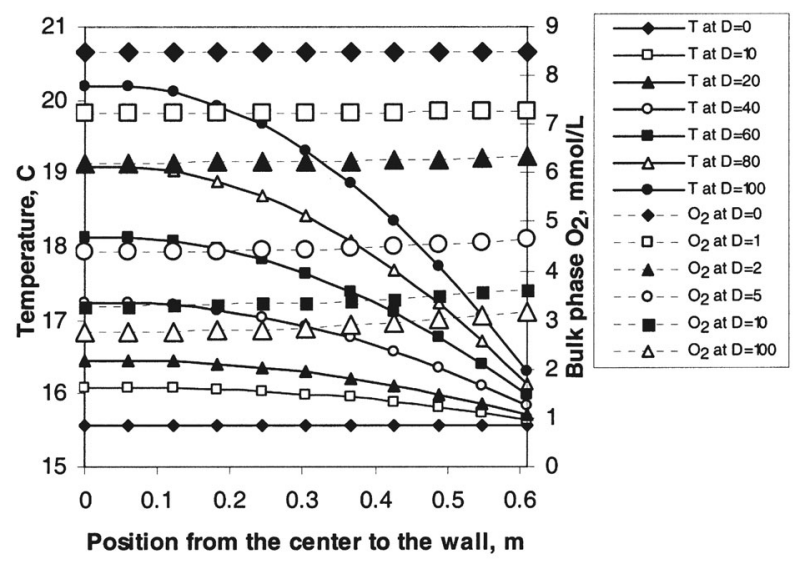

Figure 3. Hogshead temperature and oxygen profiles with time when placed in a cure room at a constant temperature of $15.6^{\circ} \mathrm{C}$

(13). Dissolved oxygen concentration can be calculated using Eqn. [7]. As can be seen from Figures 2 to 3, under a constant room temperature of $15.6{ }^{\circ} \mathrm{C}$, oxygen concentrations at all positions from the wall to the center throughout 100 days are above $2 \mathrm{mg} / \mathrm{L}$ which means aerobic conditions. However, anaerobic conditions could be quickly reached after about 10 days when the hogshead was placed under a constant room temperature of $26.7^{\circ} \mathrm{C}$ as shown in Figures 4 and 5. At a constant ambient temperature of either $15.6{ }^{\circ} \mathrm{C}$ or $26.7{ }^{\circ} \mathrm{C}$, the tobacco temperature in the hogshead gradually increases from the wall to the center due to thermal conduction and accumulation.

\section{The effect of $p H$}

During warehouse aging in controlled atmosphere rooms, it was observed that $\mathrm{pH}$ values varied for different hogsheads with different conditions. A few of them increased from the beginning to the end of the aging process, and a number of them decreased. It is difficult to explain the phenomena because too many chemicals were making contributions to the $\mathrm{pH}$ value, although organic acids and a few tobacco alkaloids may be regarded as the major contributors. 


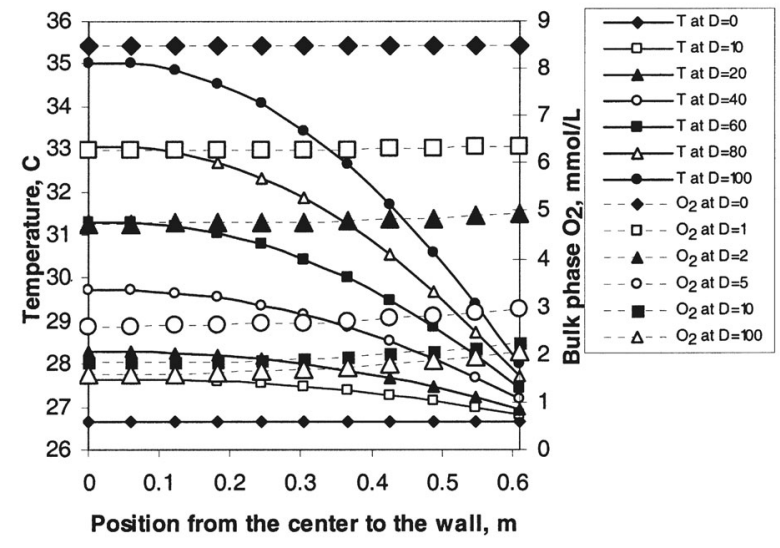

Figure 4. The temperature and oxygen profiles at different positions in the hogshead placed in a cure room with a constant temperature of $26.7^{\circ} \mathrm{C}$

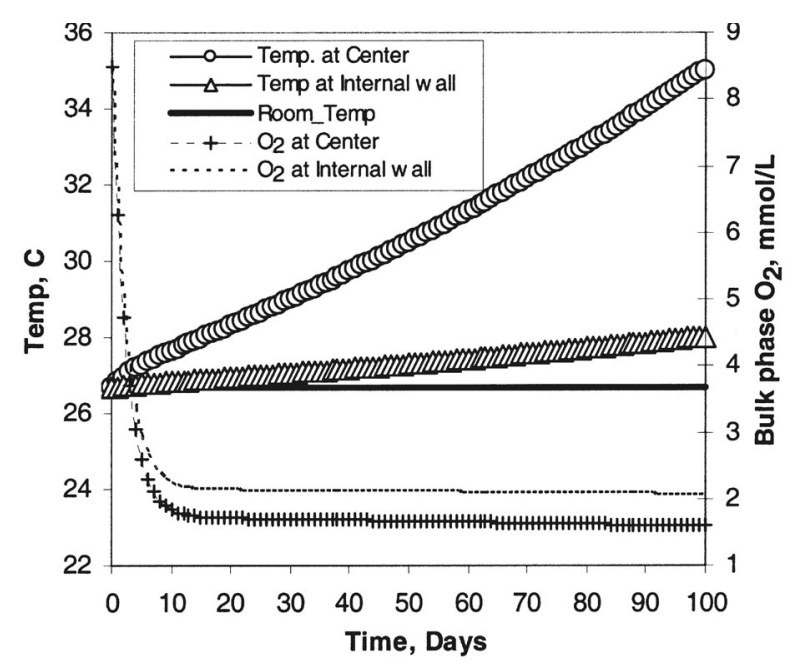

Figure 5. Hogshead temperature and oxygen profiles with time when placed in a cure room at a constant temperature of $26.7^{\circ} \mathrm{C}$

The effect of $\mathrm{pH}$ increase or decrease in the aging process on the temperature and oxygen profiles under varied ambient temperatures is shown in Figure 6. The tobacco aging process for a period of 100 days has been studied using parameters listed in Table 1 and an artificial ambient temperature profile. Apparently, the $\mathrm{pH}$ increase or decrease has little impact on the oxygen profiles. As is well known, oxygen concentrations are governed by the diffusion process and consumption reactions. The oxygen consumption reactions are mainly controlled by biological reactions which are greatly related to the temperature but not $\mathrm{pH}$ when the $\mathrm{pH}$ value is in a certain range.

Temperatures in the hogshead center are always higher than room temperatures when the $\mathrm{pH}$ increases from the start to the end of 100 days. It is interesting to note that when the $\mathrm{pH}$ decreases from the start to the end, temperatures in the center initially are greater than room temperatures, but lower than room temperatures when the room temperature passes over a low point of about $7{ }^{\circ} \mathrm{C}$. This phenomenon has been observed in warehouse experiments. The effect of temperature on oxygen profiles can be found

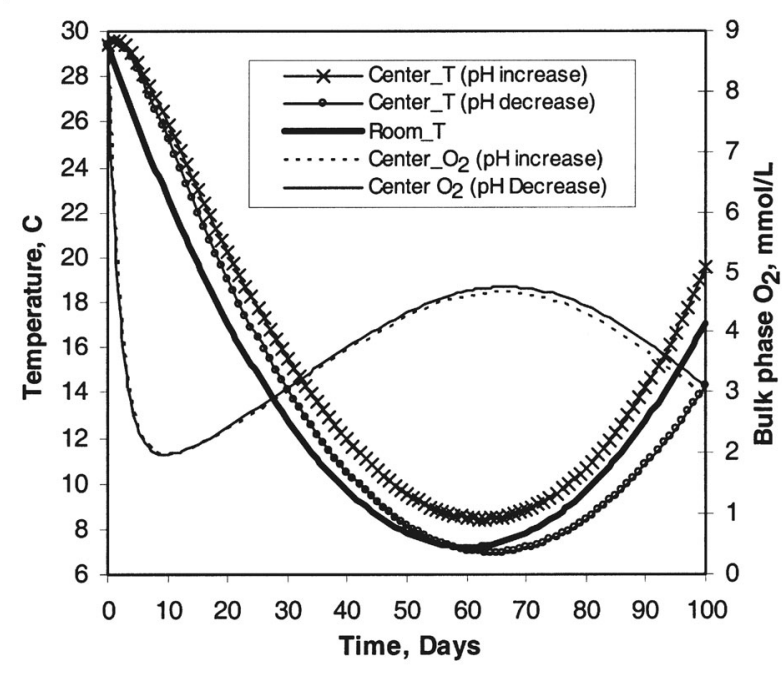

Figure 6. The effect of $\mathrm{pH}$ increase or decrease from the beginning to the end of warehouse aging on temperature and oxygen profiles

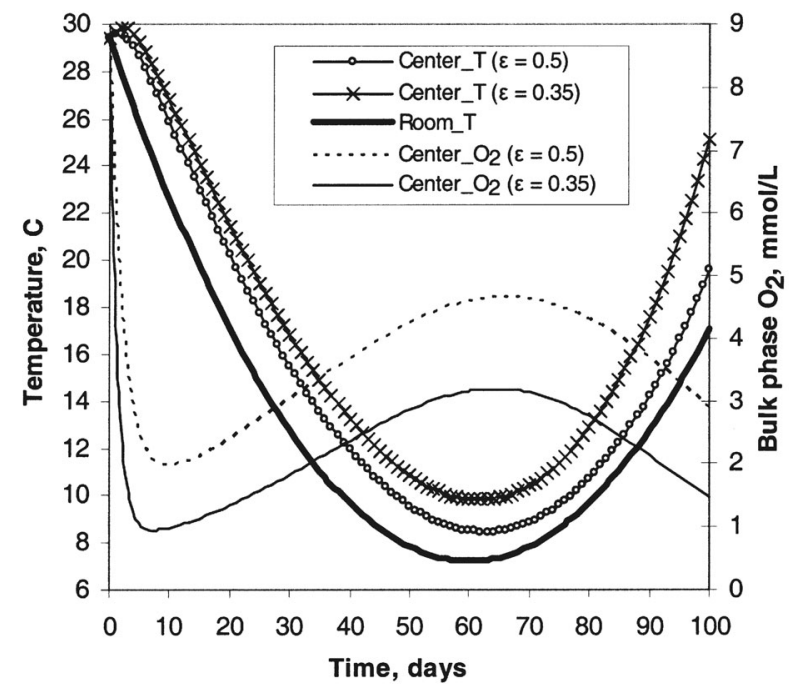

Figure 7. The effect of the void fraction in hogsheads on temperature and oxygen profiles

in Figure 6. In the initial period of around 10 days, oxygen content in the bulk phase is consumed quickly to reach to $2 \mathrm{mmol} / \mathrm{L}$ when encountering relatively higher room temperatures from $24-29{ }^{\circ} \mathrm{C}$. With the decreasing of the room temperature resulting in lower bio-activities and thus reducing oxygen consumption, the replacement of oxygen occurs by diffusion through the cracks of hogsheads. The oxygen concentrations in hogsheads are dependent upon consumption reactions and the diffusion process.

\section{The effect of void fractions}

Typical void fractions are in the range $0.35-0.4$ for column packing. The bed void fraction for tobacco packing in a hogshead may be a little greater. The void fraction reflects the packing conditions; whether tight or loose. Figure 7 shows the effect of the void fraction in the tobacco hogshead on the temperature and oxygen profiles when using parameters listed in Table 1 and assuming a $\mathrm{pH}$ increase 


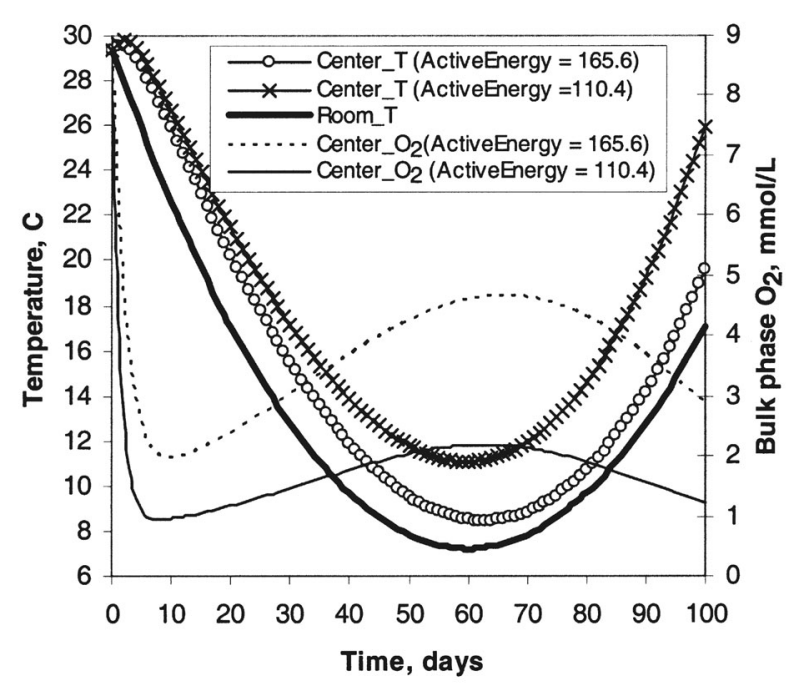

Figure 8. The effect of the reaction active energy on temperature and oxygen profiles

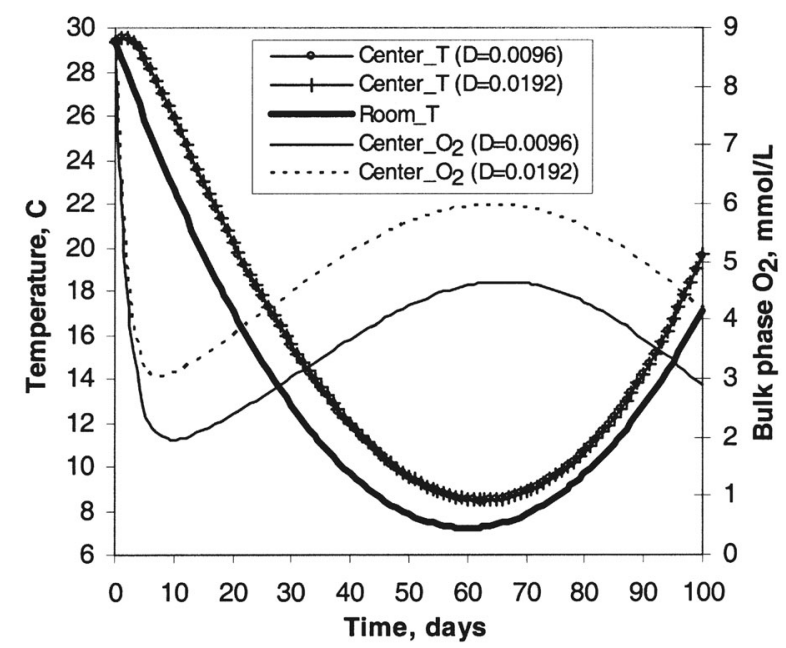

Figure 9. The effect of the oxygen diffusivity on temperature and oxygen profiles

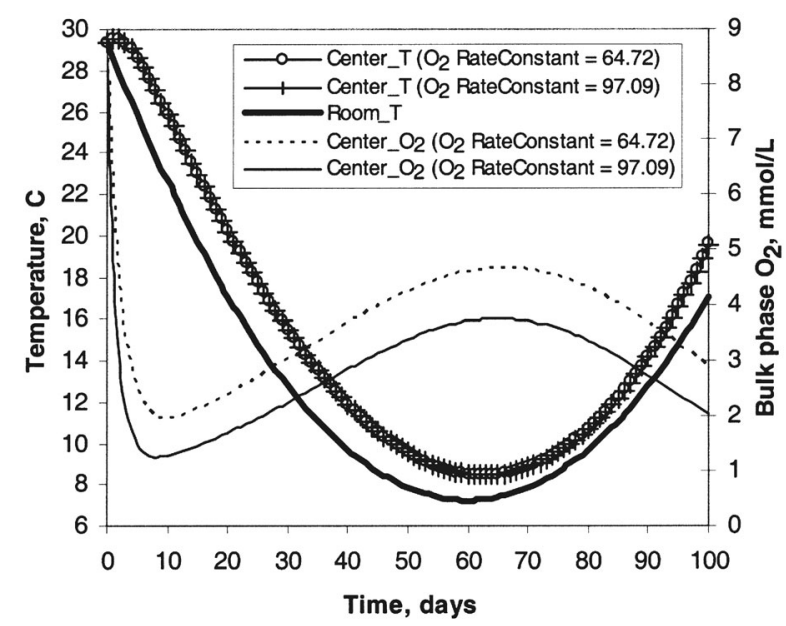

Figure 10. The effect of the rate constant for oxygen consumption on temperature and oxygen profiles from the beginning to the end of the aging process. A tobacco moisture content of $25 \%$ and an artificial ambient temperature profile are applied.

Oxygen diffusion can be facilitated at a higher void fraction (0.5) than a lower value (0.35) because of more space between tobacco leaves in hogsheads. Oxygen concentrations with a higher void fraction thus are always greater than those with a lower value as shown in Figure 7. In contrast, temperatures in the hogshead center with a lower void fraction are higher than those with a higher value throughout the process period of 100 days. This could be explained by the heat accumulated in a tight packing condition being relatively difficult to be released by thermal conduction.

\section{The effect of the reaction active energy}

Strictly speaking, the reaction active energy $E_{\mathrm{T}}$ is different from the active energy $E_{\mathrm{O}_{2}}$ for the reaction involving oxygen consumption. In order to reduce parameter numbers in the proposed model, they are set to be equal to these obtained by the regression. Active energy has been used to reflect the effect of temperature on the reaction rate. A smaller reaction active energy means a larger reaction rate. As shown in Figure 8, with a smaller active energy (110.4 $\mathrm{cal} / \mathrm{mol}$ ), oxygen concentrations can rapidly be consumed down to $1 \mathrm{mmol} / \mathrm{L}$ in less than 10 days and can not return to over $2.5 \mathrm{mmol} / \mathrm{L}$ even after oxygen replacement when the ambient temperature reaches $7{ }^{\circ} \mathrm{C}$. Because of holding a greater reaction rate, temperatures in the hogshead center are always higher than those with a larger active energy value $(165.6 \mathrm{cal} / \mathrm{mol})$.

\section{The effect of oxygen diffusivity}

Although it is hard to accurately calculate the oxygen diffusivity in tobacco packed in hogsheads, a range can be estimated based on several published correlations (14). When Reynolds number equals or approaches zero, diffusion would be dominant in the mass transfer process for oxygen in tobacco and the oxygen mass transfer coefficient can be estimated based on the Ranz-Marshall equation (14). Since it is a very slow diffusion process of oxygen from the ambient into tobacco through the cracks of the hogshead, the temperature profile in the hogshead center would not be influenced by the elevated oxygen diffusivity as shown in Figure 9. However, it could be logically correct that oxygen concentrations with a smaller oxygen diffusivity are obviously lower than those with the elevated diffusivity.

\section{The effect of the reaction rate constant for oxygen consumption}

A greater reaction rate constant means more oxygen is consumed which results in a lower oxygen profile as shown in Figure 10. However, the rate constant has little impact on the temperature profile in the hogshead center. It could be explained by biological reactions in tobacco not being very sensitive to the oxygen contents as long as oxygen levels are in a certain range. 


\section{CONCLUSIONS}

Numeric analysis has been used to solve the complex partial differential equation system and was also combined with the non-linear regression method to obtain model parameters by fitting experimental data. The proposed model can be used to predict the tobacco hogshead temperature profiles at different positions and time with different tobacco moisture contents and $\mathrm{pH}$. The model also predicts oxygen profiles in hogsheads at the same time.

The studies on effects such as $\mathrm{pH}$, void fraction, ambient temperature, reaction active energy, and oxygen diffusivity indicate that the ambient temperature does have an impact on the oxygen profiles in hogsheads. In contrast, the oxygen concentration in hogsheads has little impact on the temperature profiles. It does not mean the oxygen content is not important to the aging process. Because tobacco flavor would be influenced greatly by the aging process whether in aerobic or anaerobic conditions, measuring and recording the oxygen profile in hogsheads has been suggested for future study.

\section{NOMENCLATURE}

a model parameter in Eqn. [9]

$b \quad$ model parameter in Eqn. [9]

$C$ bulk phase oxygen concentration in the hogshead, mmol/L

$C_{0} \quad$ initial bulk phase oxygen concentration, $\mathrm{mmol} / \mathrm{L}$

$C_{\text {dissolved }}$ dissolved oxygen concentration in solid phase, $\mathrm{mg} / \mathrm{L}$

$C_{\mathrm{IS}} \quad$ bulk phase oxygen concentration at the internal wall of the hogshead, $\mathrm{mmol} / \mathrm{L}$

$C_{p} \quad$ tobacco heat capacity, cal $/\left(\mathrm{g}{ }^{\circ} \mathrm{C}\right)$

$D \quad$ oxygen diffusivity, $\mathrm{m}^{2} /$ day

$E_{\mathrm{O}_{2}}$ active energy of the oxygen consumption reaction, $\mathrm{cal} / \mathrm{mol}$

$E_{\mathrm{T}} \quad$ reaction active energy, $\mathrm{cal} / \mathrm{mol}$

$k_{\mathrm{i}} \quad$ rate constant of oxygen consumption, day ${ }^{-1}$

$k_{0} \quad$ rate constant of oxygen consumption at $0{ }^{\circ} \mathrm{C}$, day ${ }^{-1}$

$k_{\mathrm{p}} \quad$ tobacco heat conductivity, $\mathrm{cal} /\left(\mathrm{m}\right.$ day $\left.{ }^{\circ} \mathrm{C}\right)$

$K_{\mathrm{c}} \quad$ oxygen mass transfer coefficient from the external into the internal wall of the hogshead, day ${ }^{-1}$

$K_{\mathrm{LA}} \quad$ oxygen mass transfer coefficient from the internal wall into the hogshead, day ${ }^{-1}$

OV tobacco moisture content at dry weight basis, dimensionless

$R \quad$ gas constant, $\mathrm{cal} /\left(\mathrm{mol}{ }^{\circ} \mathrm{C}\right)$

$R_{\mathrm{i}} \quad$ rate of oxygen consumption reaction $i, \mathrm{mmol} /$ day

$R_{\mathrm{j}} \quad$ rate for the reaction $j, \mathrm{~mol} /\left(\mathrm{m}^{3}\right.$ day $)$

$r \quad$ radial coordinate, $\mathrm{m}$

$r_{0} \quad$ radius of the hogshead, $\mathrm{m}$

$t$ time, day

$T$ temperature, ${ }^{\circ} \mathrm{C}$

$T_{0} \quad$ initial temperature, ${ }^{\circ} \mathrm{C}$

$T_{\mathrm{R}} \quad$ room temperature, ${ }^{\circ} \mathrm{C}$

\section{Greek letters}

$\alpha \quad$ thermal diffusivity, $\mathrm{m}^{2} /$ day

$\alpha_{\mathrm{w}} \quad$ thermal diffusivity of the hogshead, $\mathrm{m}^{2} /$ day

$\beta \quad$ product of reaction enthalpies and their rates without effects of temperature, oxygen, and $\mathrm{pH}, \mathrm{cal} /\left(\mathrm{m}^{3}\right.$ day $)$

$\delta$ $\epsilon \quad$ void fraction, dimensionless

$\rho \quad$ tobacco packing density, $\mathrm{kg} / \mathrm{m}^{3}$

$\Delta H_{\mathrm{j}} \quad$ enthalpy generated by the reaction $j, \mathrm{cal} / \mathrm{mol}$

$$
\begin{array}{ll}
\text { Subscript } \\
\mathrm{i} & 1,2,3 \ldots \\
\mathrm{j} & 1,2,3 \ldots
\end{array}
$$

\section{REFERENCES}

1. Finger, S.M., R.T. Hatch, and T.M. Regan: Aerobic microbial growth in semisolid matrices: heat and mass transfer limitation; Biotech. Bioeng. XVIII (1976) 1193-1218.

2. Saucedo-Castaneda, G., G.M. Gutierrez-Rojas, G. Bacquet, M. Raimbault, and G. Viniegra-Gonzalez: Heat transfer simulation in solid substrate fermentation; Biotech. Bioeng. 35 (1990) 802-809.

3. Saucedo-Castaneda, G., B.K. Lonsane, M.M. Krishnaiah, J.M. Navarro, S. Roussos, and M. Raimbault: Maintenance of heat and water balances as a scale-up criterion for the production of ethanol by fermentation system; Process Biochem. 27 (1992) 97-105.

4. Lai, M.N., H.H. Wang, and F.W. Chang: Thermal diffusivity of solid mash of sorghum brewing-a-solid state fermentation; Biotech. Bioeng. 34 (1989) 1337-1342.

5. VanderGheynst, J.S., L.P. Walker, and J.-Y. Parlange: Energy transport in a high-solids aerobic degradation process: mathematical modeling and analysis; Biotechnol. Prog. 13 (1997) 238-248.

6. Seki, H. and T. Komori: Heat transfer in composting process; J. Agr. Met. 3 (1983) 137-179.

7. Seki, H. and T. Komori, T.: Heat transfer in composting process (part 2); J. Agr. Met. 1 (1984) 37-45.

8. Hsieh, C.M., P.C. Ho, and Y.I. Chang: Theoretical model for a non-isothermal static compost; J. Chin. I.Ch.E. 1 (1997) 37-47.

9. Robinzon, R., E. Kimmel, B. Krasovitski, and Y. Avnimelech: Estimation of bulk parameters of a composting process in windrows; J. Agric. Eng. Res. 73 (1999) 113-121.

10. Bird, R.B., W.E. Stewart, and E.N. Lightfoot: Transport Phenomena, John Wiley \& Sons, New York, 1960, pp. 554-559.

11. Banyasz, J.L.: The thermodynamics of tobacco-water interactions; Beitr. Tabakforsch. Int. 18 (1999) 189-204.

12. Seber, G.A.F. and C.J. Wild: Nonlinear Regression; Wiley, New York, 1989, pp. 10-100.

13. Haug, R.T.: Compost engineering principles and practice; $2^{\text {nd }}$ Edition, Ann Arbor Science Publishers, Ann Arbor, 1993, pp. 105-108.

14. Yang, R.T.: Gas separation by adsorption processes; Butterworths, Boston, 1987, pp. 102-115.

\section{Corresponding author:}

\section{Yizhou Zheng}

240/254

Wyeth Pharmaceutical Inc.

401 North Middletown Road

Pearl River, NY 10965

E-mail: yizhou_zheng@yahoo.com 